\title{
VARIASI PILIHAN BAHASA PADA MASYARAKAT DI KABUPATEN PROBOLINGGO: KAJIAN ETNOGRAFIS
}

\author{
Anisa Zuhria Sugeha \\ Magister Ilmu Linguistik. Universitas Airlangga \\ anisa.sugeha@gmail.com
}

\begin{abstract}
Abstrak
Penelitian ini bertujuan untuk memperoleh pemahaman mendalam tentang (1) bentuk pilihan variasi kode pada domain yang berbeda dari masyarakat Probolinggo; (2) ranah sosial dari penggunaan dialek Jawa Madura; (3) bentuk alih kode dan campur kode yang terjadi sebagai bentuk pilihan kode di masyarakat Probolinggo; (4) faktor penentu dalam pilihan variasi kode; dan (5) pola jaringan sosial yang terjadi di aktivitas komunikasi antara masyarakat Probolinggo.

Penelitian ini menggunakan pendekatan kualitatif dan metode analisis etnografis. Fokus penelitian ini adalah mengamati latar tempat masyarakat melakukan berbagai kegiatan, baik di rumah, di sekolah, di tempat kerja maupun di lingkungan tempat tinggalnya. Data penelitian yang dikumpulkan dalam penelitian ini berupa informasi dalam bentuk tuturan. Kegiatan penelitian ini terbatas hanya mencakup tiga kecamatan di Kabupaten Probolinggo, yaitu Kraksaan, Paiton dan Tongas.

Hasilnya adalah (1) variasi bentuk pilihan bahasa pada masyarakat dwibahasawan Jawa dialek Madura-Indonesia di Kabupaten Probolinggo mencakup: (a) pilihan variasi kode, (b) pilihan kode tingkat tutur yang berupa bebasan dan pasaran, (c) pilihan bahasa yang berbentuk ragam formal dan nonformal; (2) penggunaan bahasa pada masyarakat dwibahasawan di Kabupaten Probolinggo terjadi dalam berbagai ranah sosial (kekeluargaan, pekerjaan, pendidikan, keagamaan, dan ketetanggaan); (3) pilihan bahasa pada masyarakat Kabupaten Probolinggo ditandai dengan adanya peristiwa alih kode dan campur kode; (4) faktor yang mempengaruhi pemilihan bahasa penutur meliputi kepribadian, jenis kelamin, usia, dan kemampuan berbahasa. Dalam memilih kode bahasa, penutur tidak mungkin mengabaikan kondisi mitra tutur; (5) pola jaringan sosial yang terbentuk ditandai dengan tiga simpul, yaitu: (a) perbedaan status sosial, (b) kehadiran penutur ketiga, dan (c) penciptaan jarak sosial.
\end{abstract}

KATA KUNCI: Variasi bahasa, dialek, hubungan sosial

\section{PENDAHULUAN}

Pada zaman sekarang, umumnya masyarakat di dunia memiliki bilingualisme 
atau kedwibahasaan untuk berkomunikasi. Sarana komunikasi yang paling penting adalah bahasa. Bahasa digunakan sebagai sarana verbal demi terjalinnya kontak, interaksi, dan komunikasi untuk memenuhi berbagai kebutuhan. Negara Indonesia merupakan negara multietnik yang memiliki ratusan ragam bahasa. Dengan adanya keragaman bahasa tersebut menjadikan bahasa daerah menjadi salah satu penunjuk identitas etnis.

Dalam masyarakat tutur, bahasa mempunyai ragam atau variasi yang digunakan oleh masyarakat tuturnya. Dengan latar belakang budaya, social, dan situasi, masyarakat tutur dapat menentukan penggunaan bahasanya. Dalam pandangan sosiolinguistik, situasi kebahasaan pada masyarakat bilingual ataupun multilingual sangat menarik untuk diteliti.

Menurut Haugen(1972:161), bahasa adalah institusi sosial yang sejajar dengan institusi lainnya, seperti hukum, agama, atau ekonomi masyarakat, serta sekaligus menjadi sarana sosial yang memudahkan dan menghubungkan dengan institusi lainnya. Sebagai sebuah institusi, bahasa menjadi sebuah simbol kelompok masyarakat atau lembaga kemasyarakatan. Pernyataan Haugen ini diperkuat oleh pandangan Saussure (1993: 25) yang mengatakan bahwa bahasa adalah lembaga kemasyarakatan yang sama seperti lembaga kemasyarakatan lainnya, misal pernikahan dan pewarisan. Hal ini membuktikan bahwa perhatian terhadap dimensi sosial bahasa sangatlah penting. Maka dari itu, mengkaji bahasa tidak dapat dilepaskan dari hubungannya dengan masyarakat penuturnya.

Secara langsung dan tidak langsung, kajian bahasa mempunyai fungsi sosial yang memberikan gambaran tentang fenomena perubahan sosial yang terjadi dalam suatu masyarakat. Fenomena pemilihan bahasa dalam masyarakat tutur di wilayah Kabupaten Probolinggo merupakan fenomena kebahasaan yang menarik untuk dikaji. Hal ini disebabkan karena berhubungan erat dengan latar belakang bahasa ibu penuturnya, terlebih bila dikaitkan dengan adanya berbagai ragam bahasa dalam Bahasa Indonesia (BI) dan tingkat tutur dalam bahasa Jawa dialek Madura (BJM).

Penelitian berkenaan dengan fenomena variasi pilihan bahasa antara bahasa Indonesia (BI) dan bahasa daerah (BJM) di Kabupaten Probolinggo ini dapat memberikan gambaran dan deskriptif nyata yang berhubungan dengan situasi diglosik di wilayah Kabupaten Probolinggo. Penelitian ini secara teoritis dan empiris memiliki tujuan untuk menjabarkan peran dan ranah penggunaan BJM dan BI di dalam konteks komunikasi penutur di wilayah Kabupaten Probolinggo yang berkaitan dengan faktorfaktor yang dimiliki dan berlaku di dalam masyarakatnya. Penelitian ini bertujuan untuk memperoleh pemahaman mendalam tentang fenomena: 1) wujud variasi pilihan bahasa pada masyarakat Kabupaten Probolinggo; 2) ranah sosial penggunaan Bahasa 
Jawa Dialek Madura oleh masyarakat Kabupaten Probolinggo; 3) wujud alih kode dan campur kode yang terjadi pada masyarakat Kabupaten Probolinggo; 4) faktor penentu dalam variasi pilihan bahasa pada masyarakat Kabupaten Probolinggo; dan 5) pola penggunaan bahasa yang terjadi pada interaksi komunikasi masyarakat Kabupaten Probolinggo.

Ragam bahasa timbul karena kebutuhan penutur akan adanya alat komunikasi yang sesuai dengan situasi sosialnya. Menurut Suwito (1983: 148) adanya berbagai macam variasi bahasa menunjukkan bahwa penggunaan bahasa bersifat aneka ragam. Kebhinnekaan bahasa ditentukan oleh bermacam-macam aspek di luar bahasa, misalnya status sosial, usia, gender, dan etnisitas. Adanya perbedaan dialek dan aksen menjadi salah satu bukti yang keberadaannya dipengaruhi oleh aspek sosial.

Masyarakat penutur menggunakan bahasa sebagai kebutuhan komunikasi sesuai dengan situasi yang mereka hadapi. Peristiwa komunikasi meliputi tiga hal, yaitu medan (field), suasana (tenor), dan cara (mode). Medan adalah istilah yang berkaitan dengan hal atau topik, yakni tentang mengapa bahasa tersebut digunakan. Intinya, medan adalah subjek atau topik dalam suatu pembicaraan misalnya politik, ekonomi, dan teknologi. Keberagaman bahasa kelompok ini sering memperlihatkan laras bahasa atau register yang ditandai oleh adanya penggunaan jargon. Suasana merujuk pada hubungan peran pembicaraan, yaitu hubungan sosial antara penutur dengan mitra tutur yang ada dalam pembicaraan tersebut. Suasana menitikberatkan pada bagaimana pemilihan bahasa dipengaruhi oleh hubungan sosial antara penutur dan mitra tutur atau penulis dan pembaca. Menurut suasana dalam aspek kesantunan, keberagaman adalah ukuran formal dan tidaknya suatu tuturan dan status peserta tutur yang terlibat didalamnya. Suasana dapat pula dicerminkan melalui penggunaan cara menyara. Kata sapaan bapak dan ibu, konteks penggunaannya akan berbeda dengan penggunaan kata sapaan om dan tante. Lebih lanjut, suasana juga mempengaruhi ragam pemilihan bahasa dalam pembagian gaya berbahasa, seperti ragam intim, santai, formal, konsultatif, dan beku.

Cara merujuk pada peran yang dimainkan oleh bahasa dalam komunikasi, termasuk peran yang terhubung dengan jalur yang digunakan saat berkomunikasi. Yang dimaksud jalur disini adalah apakah pesan disampaikan dengan bahasa tulis, lisan, tulis untuk dilisankan, dan lisan untuk dituliskan. Berkomunikasi melalui surat akan berbeda ragam bahasanya, apalagi bila dibandingkan ragam bahasa saat berkomunikasi tatap muka. Dalam masyarakat multilingual seperti negara kita, tersedia beragam kode, baik berupa bahasa, variasi, dialek maupun gaya yang dapat digunakan dalam interaksi sosial. Dengan adanya kode-kode tersebut dalam interaksi sehari-hari, anggota masyarakat akan memilih kode yang sesuai dengan kebutuhan dan faktor- 
faktor yang mempengaruhinya.

Terdapat tiga kategori dalam pemilihan bahasa, yaitu pertama, memilih salah satu variasi dari bahasa yang sama (intralanguage variation); kedua, melakukan alih kode (code switching) yang artinya memakai satu bahasa untuk satu keperluan dan memakai bahasa lain untuk kepentingan lain dalam situasi tutur; ketiga, melakukan campur kode (code mixing) yang artinya memakai campuran bahasa berupa serpihanserpihan bahasa lain ketika memakai suatu bahasa dalam situasi tutur. Proses pemilihan bahasa biasanya ditandai dengan sekumpulan situasi interaksi yang dikelompokkan berdasarkan bidang pengalaman yang sama dan dipertaruhkan oleh tujuan dan kewajiban bersama, misalnya keluarga, tetangga, agama, pekerjaan, dan lain-lain. Ranah-ranah yang relevan dalam suatu masyarakat mengelompokkan tindak tutur dan peristiwa tutur ke dalam kelompok-kelompok situasi sosiolinguistik yang komponennya sama di antara mereka dan biasanya dibarengi oleh pemakaian bahasa atau ragam bahasa yang sesuai. Konsep ini biasanya berlaku karena adanya alih bahasa (language-switching) pada masyarakat aneka bahasa dan masyarakat diglosik. Dalam konteks ini, ranah-ranah yang berbeda menghendaki pemakaian bahasa atau ragam bahasa yang berbeda pula. Dapat dikatakan bahwa ranah merupakan pertalian antara status partisipan tutur, latar peristiwa tutur, dan topik pembicaraan. Faktor-faktor yang memengaruhi pemilihan bahasa berbeda-beda untuk tiap masyarakat multilingual. Terdapat banyak faktor yang memengaruhi pemilihan bahasa, yakni partisipan, situasi, isi pembicaraan, fungsi, serta tujuan interaksi.

\section{METODE PENELITIAN}

Penelitian ini dilaksanakan di daerah Probolinggo. Yang dimaksud daerah Probolinggo dalam penelitian ini adalah wilayah Kabupaten Probolinggo yang terdiri atas enam kecamatan. Lokasi penelitian dibatasi pada tiga kecamatan, yaitu Kecamatan Kraksaan, Kecamatan Paiton, dan Kecamatan Tongas. Latar penelitian diarahkan pada berbagai peristiwa tutur yang terjadi di dalam semua ranah sosial, baik di lingkungan rumah, sekolah maupun kerja.

Penelitian ini menggunakan pendekatan kualitatif dan metode etnografis. Fokus penelitian ini adalah mengamati latar tempat masyarakat melakukan bermacammacam kegiatan, baik di rumah, di sekolah, di tempat kerja maupun di lingkungan tempat tinggalnya. Data penelitian yang dikumpulkan dalam penelitian ini berupa informasi dalam bentuk kata-kata atau ujaran. Data tersebut tersebut digali dari dua sumber yaitu: (1) peristiwa, yaitu semua peristiwa komunikasi yang terjadi pada masyarakat dalam ranah kekeluargaan, pekerjaan, pendidikan, keagamaan, dan ketetanggaan yang diambil menggunakan teknik simak, rekam catat; (2) informan, 
yaitu memilih dan mewawancarai beberapa orang dari masyarakat yang diperkirakan mempunyai atau pernah mempunyai kedekatan dengan masalah yang sedang diteliti.

Data primer berupa tuturan atau bagian tuturan lisan (kata, frasa dan kalimat) dari seluruh peristiwa tutur dalam semua ranah sosial. Data sekunder berupa informasi atau keterangan tentang latar budaya, social. dan situasional sebagai hasil dari pengamatan dan wawancara. Sehubungan dengan penelitian ini, data primer berupa tuturan lisan dari bermacam-macam peristiwa tutur yang dilakukan oleh masyarakat di Kabupaten Probolinggo. Sementara, data sekunder berupa informasi atau keterangan yang menjadi konteks tutur, baik berupa konteks budaya, sosial maupun situasional yang menjadi latar dari berlangsungnya peristiwa tutur.

Analisis data dalam penelitian ini menggunakan teknik yang disarankan Spradley. Penggunaan teknik ini dimaksudkan untuk memperoleh gambaran yang jelas tentang pemilihan bahasa oleh masyarakat Kabupaten Probolinggo melalui analisis domain (langkah ke-5), pengamatan terfokus (langkah ke-6), analisis taksonomi (langkah ke-7), pengamatan terpilih (langkah ke-8), analisis komponen (langkah ke9), dan analisis tema (langkah ke-10). Menurut Spradley, langkah-langkah kelima sampai dengan kesepuluh itu didahului dengan langkah-langkah pertama sampai keempat, yaitu dengan pemilihan situasi sosial yang menjadi subjek penelitian sampai dengan pengamatan deskriptif dan diakhiri dengan penemuan-penemuan budaya dan penulisan etnografis sebagai langkah kesebelas dan kedua belas. Teknik ini secara terperinci disebut The D.R.S (The Developmental Research Sequence).

Pemeriksaan keabsahan data yang digunakan dalam peneitian ini sesuai dengan kriteria Moleong (1992:173-177), yaitu keterpercayaan, keteralihan, ketergantungan, dan kepastian. Keterpercayaan dilakukan melalui kegiatan perpanjangan keikutsertaan ketekunan pengamatan, pengecekan anggota, dan diskusi dengan teman sejawat. Keteralihan dilakukan dengan uraian terperinci. Adapun kepastian dan kebergantungan dilakukan melalui proses auditing.

\section{HASIL DAN PEMBAHASAN}

Kabupaten Probolinggo dan daerah sekitarnya terbilang istimewa secara budaya karena di wilayah ini menggunakan bahasa Jawa Probolinggo atau bahasa Jawa dialek Madura (BJM) sebagai identitas sosiokultural masyarakat penuturnya. Situasi kebahasaan masyarakat Kabupaten Probolinggo ditandai oleh penggunaan bahasa Jawa dialek Madura dan bahasa Indonesia dan segala variasinya, di samping itu terdapat pula penggunaan bahasa daerah lain dan bahasa asing. Bahasa Jawa dialek Madura dan bahasa Indonesia memiliki perannya masing-masing sehingga menjadikan masyarakat Kabupaten Probolinggo sebagai masyarakat yang diglosik. 
Berkenaan dengan hal diatas, keadaan diglosik suatu masyarakat menginginkan adanya variasi pilihan bahasa dan penilaian terhadap ragam bahasa tinggi dan rendah. Dalam konteks itu, sebagian besar masyarakat Kabupaten Probolinggo menggunakan BJM sebagai alat komunikasi utama dalam interaksi sosial. Dalam hubungan dengan kedudukannya, BJM memiliki kedudukan sebagai bahasa yang dipakai untuk berbicara dalam setiap kegiatan atau suasana tidak resmi, misalnya di lingkungan rumah, sekolah, pasar, kantor, dan sebagainya. BI digunakan dalam situasi resmi, seperti dalam rapat dinas di kantor, bahasa pengantar di sekolah, dan sebagainya.

\section{Bentuk Variasi Pilihan Bahasa}

Bentuk variasi pilihan bahasa yang dilakukan oleh masyarakat tutur di wilayah Kabupaten Probolinggo digambarkan berdasarkan data yang didapat melalui pengamatan, wawancara, dan catatan lapangan yang menjadi data penting untuk dikaji. Data yang dihasilkan melalui pengamatan berupa informasi terkait dengan praktik pemilihan bahasa yang dilakukan oleh penutur. Dalam hal ini, peristiwa tutur diawali langsung melalui komunikasi yang dilakukan oleh peserta dalam konteks waktu dan tempat yang nyata. Dalam masyarakat Kabupaten Probolinggo, tersedia berbagai kode, baik berupa bahasa, gaya, dialek, maupun variasi yang dapat dipakai dalam interaksi sosial. Dengan adanya kode-kode tersebut dalam interaksi sehari-hari, kode yang tersedia akan dipilih oleh anggota masyarakat sesuai dengan kebutuhan dan faktor-faktor yang mempengaruhinya. Pemilihan variasi kode bahasa tersebut memunculkan fenomena wacana komunikasi yang sangat kompleks dan khas karena ciri sosiokultural masyarakat penuturnya ditunjukkan. Variasi bahasa pada bagian ini mencakup dua hal, yaitu kode yang berbentuk bahasa dan kode yang berbentuk tingkat tutur. Kedua jenis kode tersebut dipakai sebagai sarana komunikasi dalam bermacammacam ranah sosial masyarakat Kabupaten Probolinggo. Kode yang berbentuk bahasa meliputi kode dari bahasa Jawa dialek Madura, bahasa Indonesia, bahasa Madura, dan bahasa lainnya. Kode yang berbentuk tingkat tutur meliputi kode tingkat tutur halus atau bebasan dan kode tingkat tutur kasar atau pasaran.

a) Kode yang berbentuk Bahasa.

Data dari peristiwa tutur menunjukkan bahwa kode yang berwujud bahasa dominan digunakan dalam komunikasi pada masyarakat tutur bahasa Jawa dialek Madura di Kabupaten Probolinggo terdapat beberapa kode, yakni (1) bahasa Jawa dialek Madura, (2) bahasa Indonesia, (3) bahasa Madura, (4) bahasa Inggris, (5) bahasa Arab, dan (6) bahasa Cina. Situasi tutur menjadi penentu dalam pilihan kode tersebut, seperti peserta tutur dan hubungan antarpenutur dan konteks tutur. Dapat dikatakan bahwa situasi yang terjadi 
sangat menentukan kapan kode-kode tersebut akan digunakan. Dari beberapa peristiwa tutur yang terjadi dalam masyarakat Kabupaten Probolinggo, bahasa Jawa dialek Madura yang paling dominan digunakan. Hal ini dikarenakan adanya kenyataan bahwa di wilayah Kabupaten Probolinggo mayoritas penutur sejati adalah bahasa Jawa dialek Madura.

b) Kode yang Berbentuk Tingkat Tutur

Dari kegiatan pengumpulan data yang dilakukan, ketika dicermati, pemakaian bahasa oleh masyarakat tutur Kabupaten Probolinggo saat ini hanya mengenal dua macam tingkat tutur saja, yaitu bebasan yang merujuk pada bahasa tingkat tutur kromo dan pasaran yang merujuk pada bahasa tingkat tutur ngoko.

c) Kode yang Bentuk Ragam Bahasa

Selain kode dalam bentuk bahasa dan tingkat tutur, terdapat pula kode dalam bentuk ragam (style) yang digunakan masyarakat Kabupaten Probolinggo dalam interaksi sosial. Ragam adalah variasi bahasa yang perbedaannya ditentukan oleh adanya situasi bahasa yang berbeda. Pilihan bahasa dalam bentuk ragam pada masyarakat Kabupaten Probolinggo dapat dibedakan atas ragam formal dan ragam nonformal.

\section{Ranah Penggunaan Bahasa}

a. Ranah Keluarga

Data menunjukkan bahwa pada umumnya masyarakat tutur yang tinggal di desa cenderung memilih menggunakan bahasa Jawa dialek Madura dalam interaksi verbal dengan sesama anggota keluarga. Bahasa tingkat tutur pasaran adalah yang paling dominan digunakan. Adapun bahasa tingkat tutur bebasan lebih banyak digunakan antara peserta tutur cucu dengan kakek/nenek dan menantu-mertua.

Pada masyarakat perkotaan, terdapat kecenderungan menggunakan bahasa campuran, baik berupa alih kode ataupun campur kode dengan dominasi bahasa Jawa dialek Madura. Pada masyarakat perkotaan yang umumnya tinggal di daerah perumahan, ada kecenderungan yang menarik, yaitu terjadinya penggunaan bahasa Indonesia yang diselingi campur kode bahasa Jawa dialek Madura.

b. Ranah Pendidikan

Dalam ranah pendidikan, interaksi verbal yang dilakukan merujuk pada latar sekolah dengan partisipan siswa, guru, kepala sekolah, dan pegawai administrasinya. Bahasa pengantar di sekolah dalam proses belajar mengajar pada umumnya bahasa Indonesia, baik di sekolah dasar (pedesaan dan perkotaan), sekolah lanjutan, maupun akademi/perguruan tinggi. Oleh karena itu, intensitas 
penggunaan bahasa Indonesia dalam ranah sekolah sangat tinggi. Namun, di TK ataupun sekolah dasar kelas bawah (kelas I, II, dan III), khususnya di pedesaan masih banyak digunakan bahasa Jawa dialek Madura sebagai bahasa pengantar. Hal ini disebabkan pada umumnya bahasa pertama siswa adalah bahasa Jawa Dialek Madura, sedangkan penguasaan bahasa Indonesia sebagai bahasa kedua masih kurang.

Di samping itu, penggunaan bahasa Jawa dialek Madura banyak dijumpai pada pembicaraan di luar kelas yang bersifat santai, baik antar sesama siswa, siswa dan guru, maupun sesama guru. Bagi siswa atau guru yang kurang memahami bahasa Jawa dialek Madura akan memakai bahasa campuran, yaitu bahasa Indonesia dan bahasa Jawa dialek Madura

c. Ranah Pekerjaan

Interaksi verbal yang diamati pada ranah pemerintahan terjadi pada latar kantor kelurahan/kepala desa dan kantor kecamatan. Peserta tutur yang terlibat dalam ranah pemerintahan mencakup pegawai kelurahan/desa, lurah/kepala desa/kecamatan, penduduk, dan tamu dari instansi lain. Para pegawai kelurahan/ kecamatan dalam melayani penduduk yang mengurus berbagai keperluan umumnya menggunakan bahasa Jawa dialek Madura, menggunakan tingkat tutur bebasan kepada yang lebih tua atau dihormati dan menggunakan tingkat tutur pasaran kepada yang sebaya atau kepada yang lebih muda. Akan tetapi, jika yang datang itu tampaknya orang "asing” di kampungnya, biasanya ditegur dulu dengan bahasa Indonesia, meskipun kemudian beralih ke bahasa Jawa dialek Madura apabila pembicaranya telah semakin akrab atau bisa menggunakan bahasa Jawa dialek Madura. Terhadap lurah dan teman sekerja terdapat kecenderungan penggunaan bahasa Jawa dialek Madura dan hanya dalam situasi resmi (misalnya dalam rapat) menggunakan bahasa Indonesia. Jika ada petugas dari pemerintahan tingkat atasannya (misalnya dari kecamatan) datang ke kantor kelurahan, mulamula mereka akan ditegur dengan salam bahasa Jawa Dialek Madura seperti misalnya "Katuran, Pak". Namun, ketika berada dalam situasi resmi (misalnya dalam rapat) mereka saling berbahasa Indonesia. Bahasa Jawa Dialek Madura digunakan selama maksud kedatangan dinasnya belum dikemukakan. Setelah pembicaraan tentang kedinasan dimulai, mereka segera beralih ke bahasa Indonesia meskipun di sela-sela pembicaraannya terselip kata-kata bahasa Jawa dialek Madura (dalam wujud alih kode dan campur kode).

d. Ranah Keagamaan

Dalam ranah keagamaan, penggunaan bahasa dijumpai pada khotbahkhotbah. Juru khotbah di masjid pada umumnya memilih bahasa Arab yang 
diselingi dengan bahasa Indonesia dan bahasa Jawa dialek Madura, tetapi di daerah perumahan kadang-kadang menggunakan bahasa Indonesia yang diselingi bahasa Jawa dialek Madura dan bahasa Arab. Sedikit sekali khotbah yang disampaikan dalam bahasa Jawa dialek Madura di per-Kabupatenan. Masyarakat yang beragama Islam, khususnya di pedesaan, sebagian besar menggunakan bahasa Arab pada saat menyampaikan khotbah Jumat, sedangkan pada khotbah hari besar keagamaan lebih banyak menggunakan bahasa Indonesia. Bila khotib-nya sudah berusia lanjut biasanya masih menggunakan bahasa Jawa dialek Madura, khotbah hari Raya sudah memakai bahasa Indonesia karena umumnya jemaah yang datang bersifat heterogen.

Hubungan dengan ranah keagamaan di pesantren, data memperlihatkan bahwa bahasa Jawa dialek Madura masih sangat dominan dipakai dalam komunikasi antarsantri, santri dan ustad/kyai, kecuali kalau berbicara dengan mitra tutur diluar masyarakat Kabupaten Probolinggo. Dalam komunikasi antarsantri bahasa Jawa Dialek Madura tingkat tutur pasaran sangat dominan digunakan dalam berbicara tentang topik keseharian. Pada kegiatan pengajian dan telaah kitab kuning lebih dominan menggunakan bahasa Jawa dialek Madura yang diselingi bahasa Arab. Akan tetapi, dalam kegiatan yang bersifat formal, seperti rapat para ustad dan pertemuan dengan orang tua santri menggunakan bahasa campuran antara bahasa Indonesia, bahasa Jawa dialek Madura, dan bahasa Arab.

e. Ranah Ketetanggaan

Pemilihan bahasa dalam ranah ketetanggaan, pada masyarakat tutur yang tinggal di pedesaan umumnya cenderung memilih bahasa Jawa dialek Madura dalam interaksi verbal mereka dengan sesama tetangga. Tingkat tutur yang dominan digunakan oleh semua peserta tutur adalah tingkat tutur pasaran. Adapun tingkat tutur bebasan lebih banyak digunakan pada orang yang tidak begitu akrab atau baru dikenal.

Pada masyarakat perkotaan terdapat kecenderungan memilih bahasa Indonesia sebagai sarana interaksi komunikasi, atau memakai bahasa campuran, baik berupa alih kode maupun campur kode dengan dominasi bahasa Indonesia. Pada masyarakat per-Kabupatenan ditemukan kecenderungan yang menarik adanya pemakaian bahasa Indonesia yang diselingi campur kode bahasa Jawa dialek Madura dan diwarnai dialek Madura.

\section{Bentuk Campur Alih Kode dan Campur Kode}

Alih kode yang terjadi pada peristiwa tutur masyarakat Kabupaten Probolinggo adalah akibat adanya situasi bilingualisme pada masyarakat. Alih kode 
(code switching) merupakan peristiwa perubahan kode yang dilakukan oleh penutur dari satu kode ke kode lain dalam suatu peristiwa tutur. Jika seorang penutur bahasa Jawa dialek Madura, awalnya menggunakan bahasa Jawa dialek Madura, kemudian berubah menggunakan bahasa Indonesia dalam suatu peristiwa tutur, maka ia telah melakukan alih kode dan begitu juga sebaliknya. Sesuai dengan khazanah kode dalam masyarakat Kabupaten Probolinggo, alih kode yang terjadi dalam peristiwa tutur di dalam masyarakat Kabupaten Probolinggo dapat berwujud alih bahasa, alih ragam, dan alih register. Berikut dipaparkan variasi bentuk alih kode berdasarkan bahasa utama yang digunakan.

\section{A. Variasi Bentuk Alih Kode}

1) Variasi Bentuk Alih Kode Dasar Bahasa Jawa Dialek Madura

Terdapat variasi bentuk alih kode dengan dasar bahasa Jawa dialek Madura dalam peristiwa tutur yang terjadi pada masyarakat Kabupaten Probolinggo. Kodekode yang digunakan sebagai dasar bahasa mencakupi dua kode yang berwujud ragam yaitu (1) bahasa Jawa dialek Madura pasaran (BJMP), dan (2) bahasa Jawa dialek Madura bebasan (BJMB). Sementara itu, kode perubahannya juga memiliki variasi, yaitu (1) bahasa Indonesia formal (BIF), (2) bahasa Indonesia non-formal (BINF), (3) bahasa Jawa dialek Madura pasaran (BJMP), (4) bahasa Jawa dialek Madura bebasan (BJMB), dan (5) bahasa asing (BA).

2) Alih Kode dengan Dasar Bahasa Indonesia

Terdapat beberapa variasi alih kode dari dasar bahasa Indonesia. Peristiwa tutur dalam masyarakat Kabupaten Probolinggo menunjukkan bahwa peralihan itu mempergunakan beberapa kode, yaitu (1) bahasa Jawa Dialek Madura pasaran, (2) bahasa Indonesia formal, (3) bahasa Indonesia nonformal, dan (4) bahasa Jawa dialek Madura bebasan. Dari dasar bahasa Indonesia formal, muncul alih kode dengan pilihan bahasa Jawa Dialek Madura bebasan. Peralihan kode dalam kasus ini memiliki dua variasi, yaitu (1) alih kode yang diawali dengan bahasa Indonesia formal, dan (2) alih kode yang diawali dengan bahasa Jawa Dialek Madura Pasaran.

Variasi kedua adalah alih kode yang terjadi dalam peristiwa tutur antarpenutur yang memiliki hubungan vertikal. Sebagai contoh, A adalah anak buah B di sebuah kantor kecamatan. Dalam komunikasi sehari-hari kedua penutur tersebut lebih sering menggunakan dasar bahasa bahasa Indonesia. Setiap mengawali percakapan, A lebih sering memulainya dengan bahasa Indonesia formal untuk menghormati B dalam konteks kedinasan. Selain itu, penggunaan bahasa Indonesia formal juga disebabkan karena A merasa kurang menguasai bahasa Jawa Dialek Madura bebasan. 
Alih kode dalam peristiwa tutur itu umumnya terjadi dari dasar bahasa bahasa Indonesia beralih ke bahasa Jawa Dialek Madura pasaran. A memilih kode bahasa Indonesia formal untuk menyampaikan materi pelajaran. Pada peristiwa tutur itu, A melakukan alih kode dari kode bahasa Indonesia ke dalam kode bahasa Jawa Dialek Madura pasaran. Penutur melakukan alih kode dikarenakan ingin memperjelas materi yang sedang disampaikan kepada siswa dengan menggunakan bahasa Jawa Dialek Madura. Selain itu, alih kode dalam peristiwa tutur itu dilakukan untuk mengubah suasana proses belajar mengajar dengan diselingi humor sehingga suasana belajar menjadi lebih menyenangkan siswa.

\section{B. Wujud Alih Kode}

1 Alih Kode Berwujud Frasa

Alih kode berupa klausa, yakni kode bahasa lain yang digunakan, dilakukan oleh penutur pada saat menggunakan suatu bahasa dan secara gramatikal kode tersebut digunakan terdiri atas predikat, baik disertai subjek, objek pelengkap dan keterangan maupun tidak tetapi konstruksi tersebut adalah bagian dari suatu konstruksi kalimat ujaran yang ada dalam satu kalimat.

Berikut adalah contoh alih kode berupa klausa yang dilakukan oleh partisipan:

"Sari uwis ngantuk awas ghâgghâr, Risa pegangin adeknya tuh."

'Sari sudah mengantuk awas jatuh, Risa pegang adiknya ngantuk tuh.'

2 Alih Kode Berwujud Kalimat

Alih kode berwujud kalimat tampak pada ujaran berikut ini:

"Terserahlah, menurut Neng kalau ngekos itu tambah konjem pèssè." "ghita' bellih kakanna, bhâjar kos tambâ bânnya?"

'Terserahlah, menurut Mbak kalau ngekos itu tambah mengeluarkan uang.' 'Belum beli makannya, bayar kosnya tambah banyak, kan?'

Dalam kalimat ujaran di atas, penutur melakukan alih kode dari bahasa Indonesia ke bahasa Jawa dialek Madura. Kalimat bahasa Indonesia yang dituturkan adalah "Terserahlah, menurut Neng kalau ngekos itu tambah konjem pèssè", sedangkan kalimat bahasa dialek Madura yang dituturkan adalah "ghita' bellih kakanna, bhâjar kos tambâ bânnya'?".

3 Alih Kode Berwujud Alih Ragam

Alih kode yang dilakukan oleh penutur di wilayah Kabupaten Probolinggo bukan sekadar alih kode berwujud klausa dan kalimat, melainkan pula alih kode berwujud pergantian ragam bahasa. Dalam konteks itu, ditemukan alih kode berwujud alih kode dari bahasa Jawa dialek Madura ragam pasaran ke ragam bebasan dan sebaliknya, serta bahasa Indonesia ragam nonformal ke ragam formal dan sebaliknya. 
Alih kode bahasa Jawa Dialek Madura ragam pasaran ke ragam bebasan tampak dalam cuplikan dialog berikut

Ibu 2: "Neng, brâmpah jherrukna?"

Ibu 1: "pètto ribu sakilo."

Ibu 2: "Larange, Neng, limangewu ae, ya."

Ibu 1: "Ibune kendâ' bellih brâmpah?"

Ibu 2: "Boleh apa ndak, Neng?"

Ibu 1: "Iye geh, Bu, Brâmpah?"

Ibu 2: "Rongkilo aja Neng."

Alih kode bahasa Indonesia ragam nonformal yang beralih ke ragam formal tampak dalam cuplikan dialog berikut.

P : "Assalamualakikum, Bu."

Q : "Wa'alaikumsalam, masuk Bu!" "Dipake aja sendalnya!”

P : "Nggak usah, Bu, kotor."

Q : "Wis sih nggak apa-apa, pake aja!"

P : "Gimana E, sudah sehat?"

R : "Alhamdulillah, Bu... sudah lebih baik."

Q: "ini masih meriang lagi, Bu, makanya tadi juga nggak bisa kerja, katanya sakit kepala."

$\mathrm{R}$ : "Sedikit, Bu, sakit kepala sebelah, tapi sudah minum obat agak mendingan."

Q : "Celuk mamenya, ning buri, Neng!"

P: "Mohon maaf, Bu, kedatangan saya mengganggu istirahat, Bapak. Tapi.... ya mau bagaimana lagi situasinya mendesak."

Peralihan kode berwujud ragam bahasa tampak dari ujaran partisipan P, yang dalam tuturan sebelumnya ketika berbicara dengan mitra bicara $\mathrm{Q}$ dan $\mathrm{R}$ menggunakan bahasa Indonesia ragam nonformal, kemudian beralih ke bahasa Indonesia ragam formal ketika berbicara dengan Q untuk mengutarakan maksud kedatangannya bertemu dengan suami Q.

\section{Variasi Bentuk Campur Kode}

Berdasarkan pengamatan dan data yang diperoleh, praktik campur kode yang dilakukan oleh penutur bahasa di wilayah Kabupaten Probolinggo memiliki berbagai variasi dilihat dari kode bahasa yang digunakan. Dalam hal itu, terdapat keragaman kode bahasa yang dipakai. Hal tersebut dapat dimaklumi karena sebagian besar masyarakat di wilayah Kabupaten Probolinggo merupakan penutur dwibahasawan.

Campur kode sebagai gejala kebahasaan yang dilakukan oleh penutur ditandai oleh praktik penggunaan unsur dari bahasa lain saat menggunakan bahasa tertentu. 
Dalam hal itu, unsur dari bahasa lain tersebut dilihat dari tataran kebahasaannya (tataran gramatikal) dapat berwujud kode bahasa, kata dan frasa. Dengan demikian, secara teoretis, berdasarkan tataran kebahasaannya, gejala campur kode dapat diklasifikasikan menjadi dua kategori: a) campur kode menurut kode bahasa, dan b) campur kode menurut wujud kebahasaan

\section{a) Variasi Campur Kode menurut Kode Bahasa}

Dilihat dari pilihan kode yang digunakan, gejala campur kode yang dilakukan oleh penutur bahasa di wilayah Kabupaten Probolinggo adalah variasi campur kode bahasa-bahasa berikut: (1) bahasa Jawa dialek Madura ragam bebasan; (2) bahasa Jawa dialek Madura ragam pasaran; (3) bahasa Indonesia ragam formal; dan (4) bahasa Indonesia ragam nonformal. Variasi campur kode oleh penutur di wilayah Kabupaten Probolinggo, berdasarkan kode bahasa yang digunakannya dapat diformulasikan sebagai berikut.

Tabel 1. Variasi campur kode oleh penutur di wilayah Kabupaten Probolinggo berdasarkan kode bahasa yang digunakan

\begin{tabular}{|c|c|c|c|}
\hline $\begin{array}{c}\text { Bahasa yang } \\
\text { Digunakan }\end{array}$ & $\begin{array}{c}\text { Keterangan } \\
\text { Ragam }\end{array}$ & $\begin{array}{l}\text { Bahasa Lain } \\
\text { yang } \\
\text { Dicampurkan }\end{array}$ & $\begin{array}{c}\text { Keterangan } \\
\text { Ragam }\end{array}$ \\
\hline \multirow{2}{*}{$\begin{array}{c}\text { Bahasa Jawa } \\
\text { Dialek Madura }\end{array}$} & Pasaran & \multirow{2}{*}{$\begin{array}{c}\text { Bahasa } \\
\text { Indonesia }\end{array}$} & Baku \\
\hline & Bebasan & & Tidak baku \\
\hline \multirow{3}{*}{$\begin{array}{c}\text { Bahasa Jawa } \\
\text { Dialek Madura }\end{array}$} & Pasaran & \multirow[t]{3}{*}{ Bahasa Madura } & Kasar \\
\hline & \multirow{2}{*}{ Bebasan } & & Sedang \\
\hline & & & Halus \\
\hline \multirow{3}{*}{ Bahasa Madura } & Kasar & \multirow{3}{*}{$\begin{array}{c}\text { Bahasa } \\
\text { Indonesia }\end{array}$} & Baku \\
\hline & Sedang & & \multirow{2}{*}{ Tidak Baku } \\
\hline & Halus & & \\
\hline \multirow{2}{*}{$\begin{array}{c}\text { Bahasa } \\
\text { Indonesia }\end{array}$} & Baku & \multirow{2}{*}{$\begin{array}{c}\text { Bahasa Jawa } \\
\text { Dialek Madura }\end{array}$} & Pasaran \\
\hline & Tidak Baku & & Bebasan \\
\hline \multirow{3}{*}{ Bahasa Madura } & Kasar & \multirow{3}{*}{$\begin{array}{c}\text { Bahasa Jawa } \\
\text { Dialek Madura }\end{array}$} & Pasaran \\
\hline & Sedang & & \multirow{2}{*}{ Bebasan } \\
\hline & Halus & & \\
\hline \multirow{3}{*}{$\begin{array}{c}\text { Bahasa } \\
\text { Indonesia }\end{array}$} & Baku & \multirow{3}{*}{ Bahasa Madura } & Kasar \\
\hline & \multirow{2}{*}{ Tidak Baku } & & Sedang \\
\hline & & & Halus \\
\hline
\end{tabular}

\section{b) Variasi Campur Kode menurut Wujud Kebahasaan}

1. Campur Kode yang berupa Kata

Bentuk campur kode berupa kata ditentukan dengan memperhatikan bentuk 
leksikon yang dicampurkan ke dalam tuturan. Dalam konteks itu, kode dari bahasa lain, yakni berbentuk leksikon digunakan ke dalam kalimat ujaran dalam bahasa yang digunakan. Misalnya, apabila seorang penutur sedang menggunakan bahasa Indonesia, lalu penutur tersebut memasukkan unsur bahasa Jawa dialek Madura atau sebaliknya, maka terjadi peristiwa campur kode berwujud kata, seperti contoh berikut ini.

(1) "Alhamdulillah, Pak, sehat, ada. Mari, Pak, masuk, duduk dulu nanti saya panggilin."('Alhamdulillah, Pak, sehat, ada. Silakan, Pak, masuk, duduk dulu nanti saya panggilkan')

(2) “.....tapi berhubung mobil sing ngelewati truk-truk sè bessar jrowa, ya bhenca lagi." ('....tapi berhubung yang lewat truk-truk yang besar itu, ya, rusak lagi')

(3) 'klamon ta' bâdâh aral, Neng, kendâ' èmènta bantu-bantu untuk arèh sabtoh". ('Kalau tidak ada halangan, Neng, mau diminta bantu-bantu untuk hari Sabtu')

Tuturan (1) dan (2) merupakan tuturan bahasa Indonesia, yang disisipi serpihan bahasa Jawa Dialek Madura (ragam pasaran). Kalimat tuturan (1) tuturan bahasa Indonesia yang disisipi serpihan kosakata bahasa Jawa Dialek Madura (2) merupakan tuturan bahasa Indonesia yang disisipi serpihan kata ulang dari bahasa Jawa Dialek Madura, sedangkan tuturan (3) merupakan tuturan bahasa Dialek Madura yang disisipi serpihan kosakata bahasa Indonesia.

2. Campur Kode Berupa Frasa

Dalam peristiwa campur kode, bentuk kode bahasa dari bahasa Jawa dialek Madura yang banyak disisipkan ke dalam tuturan bahasa Indonesia adalah frasa. Berikut ini adalah contoh peristiwa campur kode yang berbentuk frasa, baik dalam tuturan yang berbahasa utama BI atau sebaliknya. Dalam kalimat ujaran di atas, penggunaan frasa adverbial oleh penutur untuk menanyakan tempat keberadaan seseorang, yakni anak mitra tutur yang paling besar. Kalimat ujaran di atas sebenarnya merupakan kalimat dalam bahasa Jawa dialek Madura, tetapi penuturnya menyisipkan frasa 'ke mana' untuk menggantikan frasa dalam bahasa Jawa dialek Madura, yakni nengendi. Frasa 'ke mana' digunakan penutur agar mitra tuturnya mengerti karena mitra tuturnya bukan penutur bahasa Jawa dialek Madura.

\section{Faktor Penentu dalam Pilihan bahasa}

Sesuai dengan data dan temuan penelitian ini, diketahui bahwa faktor yang menentukan pilihan bahasa dalam peristiwa tutur yang dilakukan oleh para penutur di wilayah Kabupaten Probolinggo adalah sebagai berikut. 
Tabel 2. Faktor Penentu Pilihan Bahasa

\begin{tabular}{|c|c|c|}
\hline No. & $\begin{array}{l}\text { Faktor Penentu } \\
\text { Pilihan Bahasa }\end{array}$ & Deskripsi \\
\hline 1 & $\begin{array}{l}\text { Latar tempat } \\
\text { dimana komunikasi } \\
\text { dilangsungkan }\end{array}$ & $\begin{array}{l}\text { Dalam hal ini, pilihan bahasa yang dilakukan oleh } \\
\text { penutur di wilayah Kabupaten Probolinggo ditentukan } \\
\text { oleh di wilayah mana komunikasi dilangsungkan; apakah } \\
\text { diwilayah penuturbahasa Jawa dialek Madura ataupenutur } \\
\text { bahasa Madura. Jika peristiwa tutur dilakukan di wilayah } \\
\text { tutur bahasa Jawa Dialek Madura, maka bahasa yang } \\
\text { dipilih tentunya bahasa Jawa Dialek Madura, meskipun } \\
\text { dimungkinkan terjadi campur kode dan alih kode. Atau, } \\
\text { diawali oleh penggunaan bahasa Indonesia karena tidak } \\
\text { mengetahui asal bahasa lawan tutur, kemudian beralih ke } \\
\text { bahasa daerah (Jawa dialek Madura atau Bahasa Madura). }\end{array}$ \\
\hline 2 & $\begin{array}{l}\text { Latar belakang } \\
\text { yang dikuasai oleh } \\
\text { penutur }\end{array}$ & $\begin{array}{l}\text { Pilihan bahasa oleh penutur bahasa di Probolinggo akan } \\
\text { disesuaikan dengan kode bahasa yang digunakanoleh mitra } \\
\text { tutur, baikdenganstrategibercampurkodeatauberalihkode. }\end{array}$ \\
\hline 3 & $\begin{array}{l}\text { Latar belakang } \\
\text { bahasa mitra tutur }\end{array}$ & $\begin{array}{l}\text { Latar belakang mitra tutur sangat berperan dalam } \\
\text { pemilihan bahasa yang digunakan oleh penutur bahasa } \\
\text { di Probolinggo. Apakah bahasa yang dipilih adalah } \\
\text { bahasa daerah atau bahasa Indonesia. Pengetahuan } \\
\text { latar belakang bahasa mitra tutur ini diperoleh } \\
\text { setelah terjadi percakapan pembuka antar partisipan. }\end{array}$ \\
\hline 4 & $\begin{array}{l}\text { Respon atau } \\
\text { tanggapan dari } \\
\text { mitra tutur }\end{array}$ & $\begin{array}{l}\text { Dalam konteks tutur di wilayah Probolinggo, respon } \\
\text { yang dimaksud adalah respon verbal yang menunjukan } \\
\text { penguasaan dan kemahiran bahasa yang dimiliki oleh } \\
\text { mitra tutur atau bahasa yang dikehendaki oleh lawan tutur, } \\
\text { apakah bahasa daerahatau bahasa Indonesia, sebabadajuga } \\
\text { penutur yang menguasai bahasa daerah tetapi lebih senang } \\
\text { menggunakan bahasa Indonesia dalam berkomunikasi. }\end{array}$ \\
\hline
\end{tabular}




\begin{tabular}{|c|c|c|}
\hline 5 & $\begin{array}{l}\text { Topik yang } \\
\text { dibicarakan }\end{array}$ & $\begin{array}{l}\text { Faktor yang menjadi penentu pilihan bahasa apa yang } \\
\text { akan digunakan. Jika percakapan mengenai keseharian, } \\
\text { maka bahasa yang dipilih akan berbeda dengan pada saat } \\
\text { membicarakan hal lain yang bersifat resmi atau formal. }\end{array}$ \\
\hline 6 & Tujuan percakapan & $\begin{array}{l}\text { Faktor tujuan percakapan menjadi penentu pilihan } \\
\text { bahasa yang dilakukan oleh penutur bahasa di } \\
\text { Probolinggo. Apakah peristiwa tutur dilangsungkan } \\
\text { untuk tujuan memelihara hubungan sosial saja atau } \\
\text { kedinasan/institusi, jual beli, dan lain sebagainya. }\end{array}$ \\
\hline 7 & $\begin{array}{l}\text { Kedekatan, } \\
\text { keintiman, dan } \\
\text { jarak sosial } \\
\text { antarpartisipan }\end{array}$ & $\begin{array}{l}\text { Faktor ini ditunjukkan melalui seberapa dekat hubungan } \\
\text { antarpartisipan. Kedekatan memiliki peranan yang } \\
\text { penting dalam pilihan bahasa. Maksudnya, pilihan bahasa } \\
\text { yang digunakan penutur yang akrab dengan lawan tutur } \\
\text { akan berbeda dengan pilihan bahasa yang digunakan } \\
\text { untuk berbicara dengan lawan tutur yang tidak akrab. }\end{array}$ \\
\hline 8 & $\begin{array}{l}\text { Persamaan dan } \\
\text { perbedaan usia }\end{array}$ & $\begin{array}{l}\text { Dalam hal ini, usia menjadi salah satu pertimbangan } \\
\text { dalam pemilihan bahasa. Pilihan bahasa yang } \\
\text { akan digunakan kepada lawan yang lebih muda } \\
\text { atau sebaya, akan berbeda dengan pilihan bahasa } \\
\text { yang akan digunakan kepada lawan yang lebih tua. }\end{array}$ \\
\hline 9 & $\begin{array}{l}\text { Menunjukan } \\
\text { gengsi, prestise, } \\
\text { dan keinginan } \\
\text { untuk dihargai }\end{array}$ & $\begin{array}{l}\text { Dalamhalini,penuturmemilihbahasadenganpertimbangan } \\
\text { mendapatkan prestise atau penghargaan dari orang lain. }\end{array}$ \\
\hline 10 & $\begin{array}{l}\text { Penghormatan } \\
\text { terhadap mitra tutur }\end{array}$ & $\begin{array}{l}\text { Faktor ini secara konkret ditunjukkan oleh pilihan } \\
\text { bahasa apa yang akan dipilih untuk digunakan kepada } \\
\text { mitra tutur supaya mitra tutur merasa dirinya dihargai } \\
\text { atau dihormati, serta merasa tidak tersinggung, } \\
\text { misalnya pemilihan bahasa bebasan atau bahasa halus. }\end{array}$ \\
\hline
\end{tabular}




\begin{tabular}{|l|l|l|}
\hline 11 & $\begin{array}{l}\text { Motif ekonomi atau } \\
\text { keuntungan sosial }\end{array}$ & $\begin{array}{l}\text { Faktor ini dilakukan sebagai upaya melakukan } \\
\text { identifikasi dan afiliasi oleh penutur terhadap } \\
\text { lawan tutur sehingga menghilangkan jarak sosial. }\end{array}$ \\
\hline 12 & $\begin{array}{l}\text { Keterbatasan } \\
\text { linguistik }\end{array}$ & $\begin{array}{l}\text { Faktor ini didasari oleh defisit atau keterbatasan bahasa } \\
\text { yang dimiliki oleh partisipan. Misalnya, penutur yang } \\
\text { hanya menguasai secara terbatas atau sama sekali } \\
\text { tidak menguasai bahasa tertentu, misalnya bahasa } \\
\text { daerah akan memilih menggunakan bahasa Indonesia. } \\
\text { Atau, penutur yang hanya menguasai secara terbatas } \\
\text { bahasa Indonesia akan memilih menggunakan } \\
\text { bahasa daerah. Dalam keadaan semacam itu, terjadi } \\
\text { juga pemilihan bahasa yang disertai campur kode. }\end{array}$ \\
\hline 13 & $\begin{array}{l}\text { Faktor } \\
\text { sosiokultural }\end{array}$ & $\begin{array}{l}\text { Faktor ini berupa konvensi sosial, etiket linguistik, sikap } \\
\text { bahasa, dan norma sosial, serta prinsip kesetaraan dalam } \\
\text { komunikasi. Faktor ini merupakan variabel krusial yang } \\
\text { menentukan kelancaran komunikasi, selain faktor bahasa } \\
\text { yang sama dan pengetahuan bersama (shared knowledge). }\end{array}$ \\
\hline
\end{tabular}

Berdasarkan penjelasan di atas dapat disimpulkan bahwa faktor penentu pilihan bahasa yang ditemukan dalam peristiwa tutur yang terjadi antarpenutur bahasa Jawa dialek Madura adalah (1) peserta tutur, (2) tujuan tutur, (3) isi wacana atau pokok tutur, dan (4) norma tutur.

\section{Pola Penggunaan Bahasa dalam Interaksi Komunikasi}

Sebagai mahluk sosial pada umumnya, masyarakat Kabupaten Probolinggo tidak bisa terlepas dari kegiatan interaksi dan komunikasi antar-anggota masyarakatnya, baik yang memiliki latar belakang bahasa ibu yang sama maupun berbeda. Dalam interaksi komunikasi yang dilakukan, mereka saling berbagi informasi tentang berbagai hal. Interaksi komunikasi yang terjadi di antara anggota masyarakat membentuk suatu jaringan atau pola yang disebut dengan social network. Jaringan sosial merupakan suatu struktur sosial yang terbentuk dari simpul-simpul (yang umumnya adalah individu atau organisasi) yang terikat satu atau lebih tipe relasi spesifik seperti visi, nilai, keturunan, ide, teman, dll.

Hubungan sosial dalam analisis jaringan sosial dipandang sebagai simpul dan ikatan. Simpul merupakan aktor individu didalam jaringan, sedangkan ikatan 
merupakan hubungan antaraktor tersebut. Hasil penelitian menunjukkan bahwa jaringan sosial terbentuk pada berbagai ranah sosial, mulai dari keluarga, tetangga, rekan kerja hingga aparat pemerintah, yang cukup memiliki peranan penting dalam menentukan cara untuk memecahkan suatu permasalahan, menjalankan berbagai aktivitas kemasyarakatan, serta ikut derajat keberhasilan seorang individu dalam mencapai tujuannya. Dalam bentuk yang paling sederhana, suatu jaringan sosial merupakan peta seluruh ikatan yang relevan antarsimpul yang dikaji. Modal sosial aktor individu dapat pula ditentukan dengan menggunakan jaringan tersebut. Konsep ini sering digambarkan dalam diagram jaringan sosial yang mewujudkan simpul sebagai titik dan ikatan sebagai garis penghubungnya. Dari hasil pengamatan terhadap berbagai peristiwa tutur yang terjadi di masyarakat, sedikitnya ditemukan tiga simpul, yaitu (1) perbedaan status sosial, (2) kehadiran orang ketiga, dan (3) penciptaan jarak sosial.

\section{SIMPULAN}

Berdasarkan temuan penelitian yang sesuai dengan fokus dan subfokus permasalahan dapat dikemukakan simpulan bahwa variasi bentuk pilihan bahasa pada masyarakat dwibahasawan Jawa dialek Madura-Indonesia di Kabupaten Probolinggo mencakup: (a) pilihan kode yang berbentuk bahasa Indonesia, bahasa Jawa dialek Madura, bahasa Madura, bahasa Arab, dan bahasa Cina; (b) pilihan kode yang berupa tingkat tutur dalam bahasa Jawa dialek Madura, bebasan dan pasaran; (c) pilihan bahasa yang berbentuk ragam formal dan nonformal, baik dalam bahasa Jawa dialek Madura maupun bahasa Indonesia

Selain itu, penggunaan bahasa Jawa dialek Madura pada masyarakat dwibahasawan di Kabupaten Probolinggo terjadi dalam berbagai ranah sosial (kekeluargaan, pekerjaan, pendidikan, keagamaan, dan ketetanggaan), meskipun frekuensinya tidak sama. Di wilayah pedesaan bahasa Jawa dialek Madura mendominasi pilihan masyarakat dalam interaksi verbal. Sedangkan pada masyarakat perkotaan mulai terdapat kecenderungan memilih bahasa Indonesia sebagai sarana interaksi komunikasi, yang berdampak pada meningkatnya fenomena alih kode dan campur kode, yaitu penggunaan bahasa Indonesia yang disisipi oleh bahasa Jawa dialek Madura dan diwarnai dialek Madura. Dari pandangan linguistik gejala ini menandakan kebocoran diglosia, terutama pada ranah ketetanggaan.

Hal lain yang ditemukan adalah bahwa pilihan bahasa pada masyarakat Kabupaten Probolinggo ditandai dengan adanya peristiwa alih kode dan campur kode. Alih kode yang terjadi pada masyarakat Kabupaten Probolinggo menurut dasar bahasa utama yang digunakan, yaitu (a) alih kode dengan dasar bahasa Jawa dialek 
Madura, baik pada tingkat tutur bebasan maupun pasaran; (b) campur kode dengan dasar bahasa Indonesia yang bercampur dengan bahasa Jawa dialek Madura pasaran maupun bahasa Jawa dialek Madura bebasan, bahasa Indonesia dengan bahasa Arab, bahasa Indonesia dengan bahasa Inggris, maupun bahasa Indonesia dengan bahasa Cina, yang berdasarkan wujudnya bisa berbentuk kata atau frasa; (c) alih kode dan campur dengan dasar bahasa Madura, (4) bahasa apapun yang menjadi pilihan masyarakat masing-masing ditentukan oleh peserta tutur, tujuan tutur, pokok tutur, dan norma tutur. Begitu juga pilihan bentuk yang digunakan dalam interaksi komunikasi bergantung pada penutur, mitra tutur, dan peserta tutur ketiga. Faktor penutur meliputi kepribadian, jenis kelamin, usia, dan kemampuan berbahasa. Dalam memilih kode bahasa, penutur tidak mungkin mengabaikan kondisi mitra tutur, baik dalam dimensi vertikal maupun horizontal.

Berbagai tujuan tutur dapat diungkapkan dalam bahasa Jawa dialek Madura, bahasa Madura, atau bahasa Indonesia, tetapi masing-masing tujuan tutur memerlukan gaya tutur yang ditandai dengan intonasi, pilihan kata, dan topik. Tujuan tutur yang ditemukan dalam penelitian ini terdiri atas lima kategori, yaitu representatif, direktif, ekspresif, komisif, dan deklaratif. Faktor pokok tuturyang mempengaruhi pilihan bahasa berkaitan dengan pilihan kode yang berupa istilah atau ungkapan yang sesuai dengan pokok tutur yang dibicarakan dalam peristiwa tutur. Norma tutur yang mempengaruhi pilihan bahasa meliputi sikap tenggang rasa, rendah hati, dan keselarasan, (5) terdapat sekurang-kurangnya duabelas pola jaringan sosial dalam peristiwa pemilihan bahasa yang dilakukan oleh masyarakat Probolinggo. Pola jaringan sosial yang terbentuk ditandai dengan tiga simpul, yaitu: (a) perbedaan status sosial, (b) kehadiran penutur ketiga, dan (c) penciptaan jarak sosial.

\section{DAFTAR PUSTAKA}

Alwasilah, C.A. (1993). Pengantar Sosiologi Bahasa. Bandung: Angkasa.

Appel, R, Hubers, G., \& Meijer, G. (1979) Sosiolinguistiek. Amsterdam: Uitgeverij Het Spectrum

Beardsmore, H.B. (1982). Bilingualism: basic Principles. Brussel: Vrije Universiteit Brussel.

Blanc, H.A., \& Hammers, J.F. (1993). Bilinguality \& Bilingualism. Melbourne: Cambridge University Press.

Coulmas, F. (Ed.). (1997). The Handbook of Sociolinguistics. Cambridge: Blackwell.

Coulmas, F. (2005). The Study of Speakers Choices. Cambridge: Cambridge University Press.

Eckert, P. (1997). “Age as Sociolinguistics Variable” dalam Florian Coulmas (ed.) 
The Handbook of Sociolinguistics. Blackwell.

Fasold, R. W, \& Shuy, R.W. (Ed.). (1974). Studies in Language Variation. Washington: Georgetown University Press.

Fasold, R. (1984). The Sociolinguistics of Society. Oxford: Basil Blackwell Publisher Ltd.

Fishman J.A. (1972). Reading in the Sociology of Language. Paris: Mouton the Hauge.

Giles, H. (Ed.). (1977). Language, Ethnicity and Intergroup. London: Academic Press.

Grosjean, F. (1982). Life with Two Languages. USA: President and Fellow of Hardvard College.

Gumperz, J.J \& Hymes, D. (1972). Directions in Sociolinguistics: The Ethnography of Communication. Sydney: Holt, Rinehart and Winston Inc.

Haugen, E. (1993). “The Ecology of Language” dalam Anwar S. Dill (ed) The Ecology of Madura, Karyawan Departemen Pendidikan dan Kebudayaan”. Disertasi Universitas Indonesia.

Iskandar, wassid, et al. (1985). Struktur Bahasa Jawa Dialek Madura. Jakarta: Pusat Pembinaan dan Pengembangan Bahasa Depdikbud.

Millroy, L., \& Musyken, P. (1995). One Speaker, Two Languages: Cross-Diciplinary Perspectives on Code-Switching. Melbourne: Cambridge University.

Moleong, L.J. (1992). Metode Penelitian Kualitatif. Bandung: Remaja Rosdakarya

Nababan, S.U.B. (1991). Sosiolinguistik: Suatu Pengantar. Jakarta: gramedia

Pateda, M. (1987). Sosiolinguistik. Bandung: angkasa

Suwito (1983). Pengantar Awal Sosiolinguistik Teori dan Problema. Surakarta: Henary Offset Solo

Suwito. (1987). "Berbahasa dalam Situasi Diglosik: Kajian Kendala Pemilihan dan Pemilahan Bahasa di dalam Masyarakat Tutur Jawa di Tiga Kelurahan Kabupaten madya Surakarta”. Disertasi Universitas Indonesia.

Wardhaugh, R. (1998). An Introduction to Sociolingustics. Oxford: Blackwell Publisher Ltd.

Weinrich, U. (1976). Language in Contact. Paris: Mouton the Hague.

Wijana, I.D.P. \& Rohmadi, M. (2006). Sosiolinguistik: Kajian Teori dan Analisis. Yogyakarta: Pustaka Pelajar. 